over, "unless he shall reside and practise his profession of surgeon within five miles, by highway or road, from the General Post-Office in St. Martin's-le-Grand;" and also the further injustice of removing him from the council when "he shall cease to reside and practise his profession of surgeon within five miles of the General Post-Office aforesaid."

Most sincerely do I hope that the fellows will exercise the important privilege of election, on the first Thursday in July, with prudence and discretion, selecting those gentlemen who are likely to reflect honour on the College, and rejecting such as have fewer claims to recommend them.

$$
\text { wirksworth, June, 1849. I remain, } \begin{array}{r}
\text { Tir, \&c. } \\
\text { Thomas Poxser, F.R.O.S. }
\end{array}
$$

\section{GRADUATES OF THE UNIVERSITY OF LONDON.} To the Editor of THE LANCET.

Srn,-We should be glad to have substituted for the term "undergraduates," which, we think, must be a mistake on the part of the printer, the term "graduates," in the communication you did us the favour of publishing in your journal of last week. We regret to find you have misunderstoud, or have attached an undue signification to, the word "semi-official," employed by us, in allusion to certain occasional conversations which have taken place between some of our brother graduates, and those members of the College of Physicians, whose observations, believing that these gentlemen were more immediately concerned in the formation and support of the charter, we were induced to regard as really representing the state of feeling then existing in the college, and therefore sufficient to justify the use of the term. It is, perhaps, unnecessary to add, that it was very far from our intention to assert that an official correspondence has been going on between the College of Physicians and any of the graduates of the London University, or to proceed farther in explanation of the meaning we intended to convey by the use of the term "semiofficial."

The remarks you have thought proper to make, on the im propriety of partial and selfish measures, such as tend to sacrifice the interests of many to the few, carry with them an unjust imputation on our motives for addressing ourselves to the graduates' committee. Those of your readers who may feel inclined to go carefully through the Address, cannot fail to perceive that, whilst we advocate strongly the immediate adoption of a conciliatory process, we are not less urgent for the utter abolition of that pre-eminently partial and worthless expedient, the year of grace, together with every other temporary measure of the same kind, or indeed of any kind not permanent in its operation.

Out of ten or a dozen plans under which the ingenuity of a contemporary has barely succeeded in arranging the multitudinous theories of the day, each having for its avowed object the speedy settlement of the Medical Reform question, we selected and pointed out a few of the difficulties likely to be in the way of a successful negotiation, unless something were conceded on both sides. It was here, perhaps, that you thought us less explicit than we might be; but we could scarcely say anything more definite on this head without appearing to dictate to our committee, on whom we are disposed to place all possible relianee.

Finally, in recommending an immediate interview between the proper parties, we gave our reasons for believing that one part of the Charter-that part relating to the admission of Londou graduates-might be anticipated. This word anticipated alone, we are inclined to think, ought to have saved us from any observation reflecting unfavourably on our reasons for wishing to occupy so much space in your pages.

We remain, Sir, your obedient servants,

Henry Savage, M.D.

C. H. F. Rovth, M.D.

R. D. PyPer, M.D.

\section{ON THE USE OF GLYCERINE IN DEAFNESS.}

\section{To the Editor of THE LANCET.}

SrR,-Having seen the mode of application of Glycerine, adopted by Mr. Wakley, for the relief of deafness, I was induced to make trial of it myself in several cases, and $I$ have much pleasure in bearing witness to its remarkable success. It is now about six months sinee my first experiments were made, at the suggestion of Mr. Wakley. One of these cases was most striking. The patient had suffered from deafness for many years:- the meatus was dry, and the-membrana tympani polished and imperforate. On the day after the appli- cation of the Glycerine, he wrote to inform me, that he heard completely, and, by an occasional repetition of the remedy, has contiuued to do so until the present time; indeed, I anticipate that, by the occasional use of the same means, his hearing will be permanently restored.

I am, Sir, your obedient servant,

$$
\text { Erasmus Wrison. }
$$

Henrietta-street, Cavendish-square, June 16, 1849

\section{To the Editor of The Lanoet.}

SrR,-Seeing with great pleasure the paper of Mr. Thomas Wakley, jun., on the employment of glycerine in disorders of the ear and defective hearing, in the last week's LANCET, I have much satisfaction in adding my testimony-if, indeed, this be not altogether supererogatory-to the value of that remedy. Mr. Wakley mentioned the matter to me privately, about four months since, and perceiving at once the high probability of its being useful, from its very peculiar physical and chemical properties, I procured and tried the glycerine. In the very first case in which I used it I found Mr. Wakley's views justified, and in several cases since, in which I have had the opportunity of treating deafness, with very. few exceptions it has answered the purpose admirably.

Little can be added to Mr. Wakley's clear account and explanatory cases, except that I find it to be of the utmost importance that the glycerine should be free, not only from any trace of lead, but also, as much as possible, from wATER. Glycerine being soluble in water in all proportions, much that is found in commerce contains a large amount of water, and consequently will be less efficacious, or even useless. When entirely, or, at least, very nearly, free from water, with the specific gravity about 1.28 , it will be found most beneficial. This should always be ascertained, and that degree of density secured, as it is then thick, adhering to the surface of the air-tube; and, moreover, pure glycerine is deliquescent. This property is of great importance, as instead of drying by evaporation, or forming a film by oxidation, as in the case of essential oils, the access of atmospheric air tends to maintain the moisture of the tube, instead of drying it, thus rendering the use of cotton or other stuffing unnecessary; and how valuable this is found to be in practice, I need not say; it will commend itself to every practitioner. It is very probable that, as usual, people will be found ready to deny the value of Glycerine as a remedy in deafness; and may think themselves justified by their own failure, for fail it will if it be diluted with water in cases wherein the waterless fluid succeeds admirably.

I do not know that a detail of my cases would be acceptable; if so, they are at your service.

I remain, Sir, your obedient servant, Mortimer-street, June,1849. JoHN GAnDNER, M.D.

\section{Aneóical \$2ems.}

Royal College of Surgeors.--The following gentlemen having undergone the necessary examinations for the diploma, were admitted members of the college at the meeting of the Court of Examiners on the 15th inst::-

Batldon, William, Royston, Yorkshire.

Beatry, Thomas Carlyle, Easington, Durhara.

Dunne, Thomas J Janes, Haslar Hospital, Gosport.

Fogo, Arexander Scott, Dublin.

Garrard, Grorge Samued, Tasmania.

Hastings, Horace Crofts, Tumhlim-green.

LOKE, JOSERE, London.

Maodonald, John Denis, Berners-street, Oxford-street.

O'Reilly, Thomas, Virginia, Ireland.

Parker, Grorge, Brightlingsea, Essex.

W allace, Samued, Carshalton, Surrey.

WILson, JoHN, Lower Thames-street.

Apothecaries' Hall.-Names of gentlemen who passed their examination in the science and practice of medicine, and received certificates to practise, on Thursday,

Chatfield, George.

$$
\text { June } 14 t h, 1849 .
$$

Jon ES, GEORge Thomas, Winthall

Purppen, Edwand Edwards, Wedmore, Somerset.

Poddicombe, Alfred, Moreton Lampstead, Devon.

Prizes.-The Collegial Anatomieal Prize, founded by the council of the Royal College of Surgeons, for the best dissertation on a given subject, has just been awarded to Mr. HeNrX Grax, of Wilton-street, Grosvenor-place, a member of the 